\title{
Prevalence of contagious and environmental mastitis-causing bacteria in bulk tank milk and its relationships with milking practices of dairy cattle herds in São Miguel Island (Azores)
}

\author{
Carla Azevedo $^{1} \cdot$ Diana Pacheco $^{2} \cdot$ Luísa Soares $^{3} \cdot$ Ricardo Romão $^{2} \cdot$ Mónica Moitoso $^{3}$. \\ Jaime Maldonado $^{1} \cdot$ Roger Guix $^{1} \cdot$ João Simões $^{4}$ (i)
}

Received: 6 April 2015 / Accepted: 8 December 2015 / Published online: 30 December 2015

(C) The Author(s) 2015. This article is published with open access at Springerlink.com

\begin{abstract}
This study aimed to assess the degree of contamination of bulk tank milk (BTM) by Staphylococcus spp. and coliform bacteria and to identify major milking practices that help perpetuate them in dairy cattle herds in São Miguel Island. In July 2014, BTM was sampled and a survey concerning local milking practices was conducted on 100 herds. Semi quantitative multiplex polymerase chain reaction detected coagulase-negative staphylococci, Escherichia coli, Staphylococcus aureus, and other coliform bacteria (Klebsiella oxytoca, Klebsiella pneumoniae, and Serratia marcescens) in 100, 75, 59, and $35 \%$ of BTM, respectively. According to multivariable univariate models, on herds not using hot water for cleaning the milking machine and teat liners, there was at least 3.4 more odds $(P<0.01)$ to have $S$. aureus or coliform bacteria contamination in BTM. The likelihood of finding $S$. aureus in BTM was higher $(P<0.001)$ on herds without high hygiene during milking, when milking mastitic cows at the end, on abrupt cessation of milking at dry-off, and official milk control implementation. The glove use also favored (odds ratio (OR) $5.8 ; P<0.01$ ) the detection of coliform bacteria in BTM. Poor milking practices identified in this study should be avoided in order to decrease $S$. aureus and coliform bacteria contamination of BTM. Other factors
\end{abstract}

João Simões

jsimoes@utad.pt

1 HIPRA, Avinguda La Selva, 135, 17170 Amer, Girona, Spain

2 University of Évora, Largo dos colegiais 2, 7004-516 Évora, Portugal

3 São Miguel Young Farmers Association, Arrifes, Ponta Delgada, São Miguel 9500-372, Azores, Portugal

4 University of Trás-os-Montes e Alto Douro, Quinta de Prados, 5000-811 Vila Real, Portugal associated with milk quality in São Miguel Island also should be further investigated.

Keywords Cattle $\cdot$ Coliform bacteria $\cdot$ Epidemiology Mastitis $\cdot$ Risk factors $\cdot$ Staphylococcus aureus

\section{Introduction}

Bovine mastitis affects a high proportion of cows in dairy herds worldwide, being considered one of the major diseases causing a negative economic impact to the dairy industry (Bradley 2002). The etiopathology of cattle mastitis is multifaceted, with three main factors usually involved: exposure to microorganisms, host defense mechanisms, and environmental conditions (Zadoks et al. 2001). Information concerning prevalence and distribution of both environmental and contagious mastitis-causing bacteria (Zadoks et al. 2001; Riekerink et al. 2010), along with the identification of contributing risk factors (Leelahapongsathon et al. 2014) are crucial in order to control and/or prevent the disease.

Testing on samples from the bulk tank milk (BTM) is an accurate and effective approach for evaluating the milk quality at herd level (Cicconi-Hogan et al. 2013) and is particularly useful for the detection and identification of contagious bacteria in cows clinically affected by mastitis (Riekerink et al. 2010). Furthermore, the polymerase chain reaction (PCR) has been recently used for the specific and sensitive detection and identification of environmental and contagious mastitisrelated pathogens (Katholm et al. 2012). Taponen et al. (2009) observed that the real-time PCR method (qPCR) can detect bacteria on approximately half of the negative bacteriologic cultures.

The Azores is a group of islands in the Atlantic Ocean and are an autonomous region of Portugal. The economy of 
Azores is mainly based on agribusiness, with the dairy industry as the most important sector employing about $17.6 \%$ of the active population (Pinto 2010). In 2014, 51,684 dairy cows on pasture belonging to 1833 herds were officially reported in São Miguel Island (SDASM 2014). In 2013, 536, 074,2001 of milk were delivered to the transformation/ manufacture industry in all Azores Islands, with $65.1 \%$ being produced in São Miguel Island (SREA 2014). Due to the high fragmentation of land in the Azores, transhumance is common for many cattle herds. Consequently, several farmers use mobile milking machines, mobile unrefrigerated tanks, and water tank trucks, resulting in a quite peculiar management system. Despite the relevance of dairy farming in San Miguel Island, to our knowledge, studies assessing the microbiological milk quality of BTM and determining milking practices and bovine mastitis in São Miguel Island have not been addressed.

The aims of this study were (a) to assess contagious and environmental bacterial contamination on BTM from dairy cow herds in São Miguel Island using qPCR method and (b) to identify major milking practices that may favor milk contamination.

\section{Materials and methods}

\section{Herd selection}

Herd selection covered eight regions, representing the entire territory of São Miguel Island (Table 1). At least $25 \%$ of the herds in each region, on dependence of the local Young Farmers' Association (http://www.ajamcja.com/) were preselected considering their size and production practices. A total of 345 dairy herds housing about 12,000 producing cows ( $23 \%$ of total adults cows in the island) were considered for a preliminary screening. In order to identify independent variables for inclusion in the study, the milking procedures were recorded in a survey during veterinary visits lasting from February-June 2014.

A representative subsample of 100 herds housing 6065 cows in production were eventually enrolled in the trial. Herd size was between 20 and 260 lactating cows, most of which $(95 \%)$ were fed exclusively on pasture. The monthly report (May 2014) delivered by the local milk processing facility was also used for the somatic cell counts (SCC) from BTM.

\section{Survey}

A survey was developed based on previous veterinary visits, as well as on data from the National Mastitis Council (NMC) mastitis control plan (NMC 2001). It was always completed by the same interviewer during sampling and considered five topics (Table 2): (1) hygiene during milking procedures
Table 1 Number of farms selected according each region of S. Miguel Island $\left(25^{\circ} 30^{\prime}\right.$ West longitude and $37^{\circ} 50^{\prime}$ North latitude)

\begin{tabular}{lll}
\hline \multirow{2}{*}{ Region } & Herds & \\
\cline { 2 - 3 } & Total number $^{\mathrm{a}}$ & Selected \\
\hline Nordeste & 35 & 10 \\
Povoação & 30 & 8 \\
Vila Franca do Campo & 20 & 6 \\
Lagoa & 26 & 8 \\
Ribeira Grande/Lomba da Maia & 39 & 11 \\
Ponta Delgada & 79 & 20 \\
Arrifes & 86 & 27 \\
Sete Cidades & 30 & 10 \\
$\quad$ Total & 345 & 100 \\
\hline
\end{tabular}

a Total number of farms on dependence of São Miguel Young Farmers' Association

including udder, teats and tail cleanliness, the use of gloves and pre-dipping, teat and udder drying, removing foremilk, hygiene of teat cups after each milked cow, post-dipping, and milking mastitic cows only after milking all heathy females; (2) type and use of milking machine and/or tank (mobile or fixed machine and tank, cleanliness with hot or cold water); (3) mastitis diagnosis and treatment (implementation of the official milk control system, use of the California mastitis test, treatment based on antibiotic sensibility tests, veterinary assistance, and existence of treatment records); (4) dry cow period (abrupt cessation of milking, dry cow therapy of all cows, dry cow therapy according to antibiotic sensibility test, sealant use, and dry cows group); (5) calves management (calf suck its dam, colostrum administration, and calf for herd reposition). All responses were dichotomous (presence or absence) with the exception of hygiene during milking, udder and teats cleanliness, and tail cleanliness variables that were classified as low, medium, or high, according to the perception of the interviewer during the previous herd visits. Mobile BTM was also classified as present as the only collection device, present in combination with a fixed one or absent.

\section{Sample collection and preparation}

A total of 100 BTM samples from the 100 selected herds were collected using the Startcheck ${ }^{\circledR}$ sampling kit (HIPRA, Spain) in order to test the presence of Staphylococcus aureus, coagulase-negative staphylococci (CNS), Escherichia coli, and other coliform bacteria.

Briefly, $250 \mu \mathrm{l}$ of milk were taken from each tank, immediately after milking, using a calibrated sterile pipette. The entire sample was then transferred onto an FTA card (GE Healthcare, Barcelona, Spain), dropping it right at the center of the inoculation area (edged by a circle in the card). After drying card at room temperature (1-2 h), the sample was 
Table 2 Summary of all potential risk factors included in the different analyses

\begin{tabular}{|c|c|c|c|c|}
\hline \multicolumn{2}{|l|}{ Independent variable } & \multirow{2}{*}{$\begin{array}{l}\begin{array}{l}\text { Recording } \\
\text { method }\end{array} \\
\text { Visual }\end{array}$} & \multirow{2}{*}{$\begin{array}{l}\text { Description } \\
\text { 6-point scale }{ }^{\mathrm{a}}\end{array}$} & \multirow{2}{*}{$\begin{array}{l}\text { Breakdown category model } \\
\begin{array}{l}\text { High }(0-2) \text { vs. middle } \\
\text { or low }(3-5)\end{array}\end{array}$} \\
\hline Milking procedures & Hygiene during milking & & & \\
\hline & Udder and teats cleanliness & Visual & 4-point scale ${ }^{\mathrm{b}}$ & $\begin{array}{l}\text { High (clean) vs. middle } \\
\quad \text { or low (dirty) }\end{array}$ \\
\hline & Tail cleanliness & Visual & 4-point scale ${ }^{c}$ & $\begin{array}{l}\text { High ( } 1 \text { and } 2) \text { vs. middle } \\
\text { or low ( } 3 \text { and } 4)\end{array}$ \\
\hline & Glove use & Interview & Whether or not gloves were used & Yes vs. no \\
\hline & Pre-dipping & Interview & $\begin{array}{l}\text { Whether or not the teats where dipped } \\
\text { prior to milking }\end{array}$ & Yes vs. no \\
\hline & Teats and udder drying & Interview & Whether or not the teats and udder where dried & Yes vs. no \\
\hline & Elimination of first jets of milk & Interview & Whether or not the first jets of milk were eliminated & Yes vs. no \\
\hline & Teat cups hygiene & Interview & $\begin{array}{l}\text { Whether or not there was disinfection of teat } \\
\text { cups between cows }\end{array}$ & Yes vs. no \\
\hline & Post-dipping & Interview & Whether or not teats were dipped post milking & Yes vs. no \\
\hline & Milking mastitic cows at the end & Interview & Milk mastitic cows last & Yes vs. no \\
\hline \multirow{3}{*}{$\begin{array}{l}\text { Milking machine } \\
\text { management }\end{array}$} & Mobile milking machine & Interview & Use of a mobile milking machine & Yes vs. no \\
\hline & Hot water use & Interview & Use of hot water during milk routine & Yes vs. no \\
\hline & Milk bulk tank & Interview & Refrigerated or mobile $^{d}$ & Refrigerated vs. mobile \\
\hline \multirow[t]{5}{*}{$\begin{array}{l}\text { Mastitis diagnosis } \\
\text { and treatment }\end{array}$} & $\begin{array}{l}\text { Official milk control } \\
\text { implementation }\end{array}$ & DHI & Existence of official milk control & Yes vs. no \\
\hline & CMT use & Interview & Use of CMT & Yes vs. no \\
\hline & AST before treatment & Interview & Use of AST before treatment & Yes vs. no \\
\hline & Veterinary assistance & Interview & $\begin{array}{l}\text { Existence of veterinary assistance for mastitis } \\
\text { treatment }\end{array}$ & Yes vs. no \\
\hline & Treatment records & Interview & Existence of treatment records & Yes vs. no \\
\hline \multirow[t]{5}{*}{ Dry cow period } & $\begin{array}{l}\text { Abrupt cessation of milking at } \\
\text { dry-off }\end{array}$ & Interview & Use of abrupt cessation of milking & Abrupt vs. gradual \\
\hline & Dry cow therapy of all cows & Interview & Dry cow therapy of all cows & Yes vs. no \\
\hline & Dry cow therapy according AST & Interview & Use of dry cow therapy according to AST & Yes vs. no \\
\hline & Sealant use & Interview & Use of teat sealant & Yes vs. no \\
\hline & Dry cows groups & Interview & Existence of dry cow group & Yes vs. no \\
\hline \multirow[t]{3}{*}{ Calves } & Calf suck its dam & Interview & Calf sucks it dam & Yes vs. no \\
\hline & Colostrum administration & Interview & Administration of colostrum & Yes vs. no \\
\hline & For herd reposition & Interview & Calves for herd reposition & Yes vs. no \\
\hline
\end{tabular}

\footnotetext{
${ }^{a}$ According to Fregonesi and Leaver (2001): score 0 — rear legs and tail, belly, clean udder; score 1—rear legs or tail with only minimal dirtiness, belly, clean udder; score 2 - rear legs or tail with some dirtiness, belly, udder with minimal dirtiness; score 3 - rear legs or tail dirty, belly, udder with some dirtiness; score 4 - rear legs or tail very dirty, belly, udder dirty; score 5-rear legs or tail very dirty, belly, udder very dirty

${ }^{\mathrm{b}}$ According to Schreiner and Ruegg (2003): clean — scores 1 (free of dirty) and 2 (slightly dirty, 2-10\% of surface area); dirty-scores 3 (moderately covered with dirt, $10-30 \%$ of surface area) and 4 (moderately covered with caked dirt $>30 \%$ of surface area)

${ }^{\mathrm{c}}$ Adapted to tail from Cook (2002): score 1—no manure present; score 2 - minor splashing of manure; score 3 - distinct plaques of manure; score 4 confluent plaques of manure encrusted

${ }^{\mathrm{d}}$ Mobile tank: non-refrigerated milk bulk tank. In five farms, both refrigerated and non-refrigerated milk bulk tanks were used

$D H I$ dairy herd improvement, CMT California mastitis test, $A S T$ antibiotic sensibility test
}

placed in a plastic bag containing a silica gel desiccant and then in a mailing envelope to be posted to Diagnos Laboratory (HIPRA, Spain). Upon arrival, samples were prepared for DNA extraction. Using gloves and nuclease-free material between samples, the whole inoculation area from each FTA card was cut using scissors. The circle was divided into small pieces that were transferred to a 2-ml Eppendorf tube with safety lock (to avoid cross contamination between samples) and was labelled according to the origin. After adding $1 \mathrm{ml}$ of PCR nuclease-free water (Ambion ${ }^{\circledR}$ Nuclease-Free Water, Thermo Fisher Scientific, Inc., MA, USA), the tube was stirred by vortex for $15 \mathrm{~s}$ and then incubated $20 \mathrm{~min}$ at $100{ }^{\circ} \mathrm{C}$ in a dry block. Stirring was repeated, and the liquid and solid phases were separated by centrifugation for $5 \mathrm{~s}$ at 
maximum speed, according the manufacturer's instructions. Finally, supernatant was transferred to a new tube and subjected to DNA extraction (Koskinen et al. 2009).

\section{DNA extraction and amplification}

The extraction and amplification of the DNA were performed using the PathoProof ${ }^{\mathrm{TM}}$ Mastitis Complete-12 Kit (Thermo Fisher Scientific, Inc., MA, USA), with some modifications. Briefly, $600 \mu \mathrm{l}$ of buffer AL, $60 \mu \mathrm{l}$ of Proteinase K, and $600 \mu \mathrm{l}$ of each supernatant were transferred to a 2-ml Eppendorf tube. The mixture was stirred with vortex for $15 \mathrm{~s}$ and incubated $1 \mathrm{~h}$ at $56^{\circ} \mathrm{C}$. Stirring was repeated for $15 \mathrm{~s}$ and $600 \mu \mathrm{l}$ of ethanol was added. Subsequently, $620 \mathrm{ml}$ of the mixture was transferred to an extraction column (coupled to a collection tube for each subsequent step) and centrifuged $1 \mathrm{~min}$ at 10,000 rpm. The latter step was repeated three times till whole mixture was passed through the column. Then $500 \mu \mathrm{l}$ of buffer AW1 was added to the column and centrifuged $1 \mathrm{~min}$ at 10,000 rpm. This step was repeated with buffer AW2 but extending centrifugation to $3 \mathrm{~min}$. Finally, $50 \mu \mathrm{l}$ of buffer AE was transferred to the column, and the column was incubated $1 \mathrm{~min}$ at room temperature. Then the column was centrifuged $1 \mathrm{~min}$ at 10 , $000 \mathrm{rpm}$, and the eluted volume was kept frozen at -20 until further analysis.

\section{qPCR amplification}

DNA amplification was accomplished in a Stratagene Mx3005P instrument, using the PathoProof Master and Primer mixes as per manufacturer's instructions, in a final volume of $25 \mu$ l. A qPCR positive result was recorded when cycle threshold $(\mathrm{Ct})$ values were $\leq 37$ and a sigmoidal amplification plot was obtained. $\mathrm{Ct}$ values were considered as indicative of the amount of bacterial nucleic acid in a specimen, with lower values indicating higher bacterial titters. $\mathrm{Ct}$ values $\leq 30$ indicated high amounts of target nucleic acid in the sample $(+++)$, values $>30$ and $\leq 35$ indicated moderate amounts $(++)$, and values $>35$ and $\leq 37$ indicated low amounts $(+)$.

\section{Statistical analysis}

Descriptive statistics, including the $95 \%$ confidence intervals, were used for BTM bacteria prevalence description. Univariate univariable logistic regressions models were used considering each bacteria (nominal variable) on BTM and SCC (numerical variable). Models were considered significant at 0.05 level for likelihood ratio tests, and respective odd ratios were calculated.

In order to evaluate the influence of several practices in pathogens BTM presence, univariate multivariable logistic models were used.
Prior to building models, the multicollinearity was tested (De Vliegher et al., 2004) and an independent variable was eliminated if chi-square was $>60$ ( 1 d.f.), considering the Pearson test. Consequently, the variables "milk bulk tank" was removed and "mobile milking machine" remained in the initial model.

Each bacteria were classified as nominal variable 0 (no PCR detection) or 1 (PCR detection). All independent variables were also coded as categorical (0 or 1). Each multivariable model was building using the Hosmer and Lemeshow method (Hosmer and Lemeshow 1989). Firstly, all independent variables with $P$ value $<0.25$ for univariate associations were included on a full model. Nonsignificant variables were successively removed and compared with the previous model, including their interactions. Finally, only the main variables (and their interactions) were considered at 0.05 level for Wald test.

The JMP ${ }^{\circledR}$ software version 7 (SAS Institute Inc., 2007) was used for all analysis.

\section{Results}

\section{Prevalence of contagious and environmental pathogenics}

Of the 100 samples tested, CNS were present in $100 \%$ (95\% CI $96.3-100.0 \%)$, E. coli in $75 \%$ (95\% CI $65.782 .5 \%)$, S. aureus in $59 \%$ (95\% CI 49.2-68.1\%), and coliform bacteria in $35 \%$ (95\% CI $26.4-44.8 \%)$. The majority of the positive samples (40-89\%) showed $\mathrm{Ct}$ values $\leq 30$, indicating presence of high amounts of target nucleic acid (Table 3). $S$. aureus, E. coli, and coliform bacteria were concomitantly detected in $79.7 \%$ (47/59) and $42.4 \%$ (25/59) of BTM, respectively. Coliform bacteria and E. coli were simultaneously detected in $38.7 \%$ (29/75) of BTM. All bacteria were concomitantly detected in $22 \%(22 / 100)$ of the herds.

The somatic cell counts (SCC) from BTM were of $\leq 150$, $000 ;>150,000 \leq 250,000 ;>250,000 \leq 400,000$; or $\geq 400$, 000 cells $/ \mathrm{ml}$ in $12,47,36$, and $5 \%$ of all the herds, respectively. The minimum total bacterial count on BTM $(\leq 4000$ individual bacterial counts per $\mathrm{ml}$ ) occurred in $26 \%$ of the herds.

A significant relationship $(P \leq 0.001)$ between herds tested positive to $S$. aureus and the SCC was observed (Table 4), but not when coliform bacteria $(P=0.50)$ or $E$. coli $(P=0.07)$ BTM-positive were considered.

\section{Risk factors}

Significant influences of several practices on the presence of bacteria on BTM were observed concerning $S$. aureus and coliform bacteria, but not $E$. coli (Table 5). Milking machine cleanliness with hot water correlated $(P<0.05)$ with the 
Table 3 Proportion of qPCR positive herds to bacteria in bulk tank milk samples

\begin{tabular}{|c|c|c|c|c|c|}
\hline \multirow[t]{2}{*}{ Parameter } & & \multicolumn{4}{|c|}{ Proportion [CI $(95 \%)]$ of herds } \\
\hline & & S. aureus & $\mathrm{CNS}^{\mathrm{a}}$ & E. coli & Coliform bacteria ${ }^{\mathrm{b}}$ \\
\hline \multicolumn{2}{|l|}{ Negative } & $41.0 \%(31.9-50.8 \%)$ & - & $25.0 \%(17.5-34.3 \%)$ & $65.0 \%(55.3-73.6 \%)$ \\
\hline \multirow[t]{3}{*}{ Positive } & $>35 \leq 37 \mathrm{Ct}(+)$ & $12.0 \%(7.0-19.8 \%)$ & - & $21.0 \%(14.2-30.0 \%)$ & $6.0 \%(2.8-12.5 \%)$ \\
\hline & $>30 \leq 35 \mathrm{Ct}(++)$ & $42.0 \%(32.8-51.8 \%)$ & $89.0 \%(81.4-93.7 \%)$ & $40.0 \%(30.1-49.8 \%)$ & $15.0 \%(9.3-23.3 \%)$ \\
\hline & $\leq 30 \mathrm{Ct}(+++)$ & $5.0 \%(2.2-11.2 \%)$ & $11.0 \%(6.3-18.6 \%)$ & $14.0 \%(8.5-22.1 \%)$ & $14.0 \%(8.5-22.1 \%)$ \\
\hline
\end{tabular}

$C I(95 \%) 95 \%$ confidence interval, $C t$ threshold cycle, $(+)$ low amount of DNA detected, $(++)$ moderate amount of DNA detected, $(+++)$ high amount of DNA detected

${ }^{a}$ CNS (coagulase-negative staphylococci): S. chromogenes, S. epidermidis, S. hemolyticus, S. saprohyticus, S. simulans, S. warneri and S. xylosus

${ }^{\mathrm{b}}$ Coliform bacteria: Klebsiella oxytoca, Klebsiella pneumoniae and Serratia marcescens

detection of both of $S$. aureus and coliform bacteria. BTM from herds without high hygiene during milking, on abrupt cessation of milking, or milking mastitic cows at the end had more chances $(P<0.05)$ to be contaminated with $S$. aureus (Table 6). The official milk control implementation $(P<0.05)$ was also related with this contagious pathogen. Glove use or "calf suck its dam" factors also influenced $(P \leq 0.05)$ the presence of coliform bacteria.

\section{Discussion}

The microbiological milk quality is a key economic factor for dairy farms and pathogenic bacteria could arise from several sources (Berry et al. 2006; Rysánek et al. 2009; Bava et al. 2011), such as mastitic udders of cows, incrementing SCC, and/or during milking and milk transport to BTM.

The present study indicated a high prevalence of both contagious pathogen (S. aureus) and environmental (CNS and all coliforms) pathogens, reaching $100 \%$ for CNS. Although CNS are considered minor pathogens with a small SCC contribution for bulk milk, unless in herds with high SCC on BTM (Schukken et al. 2009), they were considered as emerging mastitis pathogens in the last decade (Pyörälä and Taponen 2009). However, CNS prevalence at cow level can range between 0 and $100 \%$ in herds (Schukken et al. 2009) presenting, in average, $12 \%$ of infected cows. According to Piessens et al. (2012), environmental sources and cow-to-cow transmission appear to be involved in the epidemiology of CNS. Probably, the CNS environmental contamination of milk had an important role on the prevalence results of our study. Further researches in Azorean dairy herds are necessary in order to evaluate the role of each source and the CNS species involved (Vanderhaeghen et al. 2015).

$S$. aureus, a major pathogen related to low mastitis cure rates (Katholm et al. 2012), was detected in $59 \%$ of the herds investigated. This finding is consistent with the prevalence ranging between 31 and $100 \%$ in Europe and in North America (Richard et al. 2006). Katholm et al. (2012) observed the presence of S. aureus in $97 \%$ of BTM from 4258 Danish herds using real-time PCR among other bacteria. A cumulative prevalence of $74 \%$ after three successive microbial cultures on BTM samples from 258 dairy herds in Prince Edward Island (Canada) was observed by Richard et al (2006). Phuektes et al. (2003) detected S. aureus in $33 \%$ of BTM from 42 Australian herds using multiplex PCR assay. In New Zealand, a country with cow management resembling that from São Miguel Island, S. aureus was repeatedly isolated from $57 \%$ of the BTM by Howard (2006).

$S$. aureus can be isolated from several animal body surfaces, from the hands of the milking operator, as well as from several utensils used during milking, mainly from the teat cups, representing important transmission mechanisms (Benić et al. 2012). Moreover, S. aureus is frequently nonresponsive to antimicrobial treatment and may remain on the udder causing a subclinical and excretory mastitis status
Table 4 Proportion of positive herds to $S$. aureus and their relation to somatic cell count on bulk tank milk

\begin{tabular}{lllll}
\hline SCC $(\text { cells } / \mathrm{ml})^{\mathrm{a}}$ & Positive herds to S. aureus & Odds ratio & CI $(95 \%)^{\mathrm{b}}$ & $P$ value \\
\hline$\leq 150,000$ & $16.7 \%(2 / 12)$ & Reference & - & - \\
$>150,000-\leq 250,000$ & $55.3 \%(26 / 47)$ & 6.2 & $1.2-31.4$ & 0.03 \\
$>250,000-\leq 400,000$ & $72.2 \%(26 / 36)$ & 13.0 & $2.4-70.1$ & 0.003 \\
$>400,000$ & $100 \%(5 / 5)$ & 46.2 & $1.9-114.1$ & 0.02 \\
\hline
\end{tabular}

${ }^{\text {a }}$ SCC somatic cell count measured from bulk tank milk according official report—June 2014

${ }^{\mathrm{b}} \mathrm{CI}(95 \%) 95 \%$ confidence interval 
Table 5 Significant effect of several practices on percentage of herds affected by $S$. aureus, E. coli, and other coliforms in bulk tank milk using multivariable logistic regression models

\begin{tabular}{|c|c|c|c|c|}
\hline Model for: & Practice (independent variable) & $\begin{array}{l}\text { Positive herds } \\
\text { without practice }\end{array}$ & $\begin{array}{l}\text { Positive herds with } \\
\text { practice }(\%)\end{array}$ & $P$ value $^{\mathrm{a}}$ \\
\hline \multirow[t]{5}{*}{ S. aureus (Whole model: $P<0.001$ ) } & High hygiene during milking & $74.2 \%(49 / 66)$ & $29.4 \%(17 / 34)$ & 0.007 \\
\hline & Hot water use & $69.8 \%(44 / 63)$ & $40.5 \%(15 / 37)$ & 0.04 \\
\hline & Official milk control implementation & $66.3 \%(53 / 80)$ & $30.0 \%(6 / 20)$ & 0.03 \\
\hline & Milking mastitic cows at the end & $67.2 \%(41 / 61)$ & $46.2 \%(18 / 39)$ & 0.04 \\
\hline & Abrupt cessation of milking & $67.4 \%(31 / 46)$ & $51.9 \%(28 / 54)$ & 0.04 \\
\hline \multirow[t]{3}{*}{ Coliforms $^{\mathrm{b}}$ (Whole model: $P<0.001$ ) } & Glove use & $40.7 \%(33 / 81)$ & $10.5 \%(2 / 19)$ & 0.05 \\
\hline & Hot water use & $46.0 \%(29 / 63)$ & $16.2 \%(6 / 37)$ & 0.01 \\
\hline & Calf suck its dam & $41.8 \%(28 / 67)$ & $21.2 \%(7 / 33)$ & 0.02 \\
\hline
\end{tabular}

${ }^{\text {a }}$ No significant interactions between factors (independent variables) were observed $(P>0.05)$

${ }^{\mathrm{b}}$ Coliform bacteria: Klebsiella oxytoca, Klebsiella pneumoniae, and Serratia marcescens

(Katholm et al. 2012). In fact, the significant odds ratio (OR 6.2-46.2) observed in BTM with SCC higher than 150, 000 cells $/ \mathrm{ml}$ (as reference) suggests that the intramammary infections were an important source of $S$. aureus in milk in this study. Although S. aureus has been detected in BTM during the following month after SCC report (June 2014), this short delay and the specific epidemiologic characteristic of the mastitis provoked by this pathogen can support, at least in part, these results. Inversely, although $E$. coli was simultaneously observed in $79.7 \%$ of BTM contaminated by $S$. aureus, no relationship was observed between global coliform occurrence and previous monthly SCC report, suggesting environmental contamination, as described by Rysanek et al. (2007).

Howard (2006) reported prevalence ratios of 51 and $11 \%$ for CNS and coliform bacteria in BTM, respectively. Katholm et al. (2012) recorded a low prevalence ratio (13\%) of Klebsiella spp. (a coliform bacteria) and a high prevalence ( $61 \%$ ) of E. coli. In our study, the prevalence of environmental bacteria in BTM was higher than the reported ones in these latter studies, suggesting an overall poor milking management in several herds.

According to the multivariable analysis approach, we observed three major milking practices that influenced the presence of $S$. aureus in BTM; herds without high hygiene during milking, milking mastitic cows at the end, and hot water use for clean and disinfection of milking machine influenced the presence of this bacteria in BTM.

S. aureus had 2.8 to 17.4 more chance to be detected in BTM from herds with poor milking hygiene. This suggests that this poor hygiene during milking could increase the risk of intramammary infection by S. aureus and consequently improve the SCC in bulk milk, like the one observed in our study. Although the presence of $S$. aureus in BMT was not influenced, considering our final model, by udder/teats and tail hygiene variables, the hygiene milking indicators (rear legs, tail, belly, and udder) used by in our study was extensive to other surfaces of body parts that can contaminate milk during milking. In fact, Schreiner and Ruegg (2004) described that $S$. aureus in milk was more frequently isolated from cows
Table 6 Odds ratios of the independent variables included in the logistic regression models

\begin{tabular}{lllll}
\hline Milk pathogens & Lack of practice & Odds ratio $^{\mathrm{a}}$ & $\begin{array}{l}\text { Interval } \\
\text { confidence } 95 \%\end{array}$ & $P$ value $^{\mathrm{b}}$ \\
\hline S. aureus & High hygiene during milking & 6.9 & $2.8-17.4$ & $<0.001$ \\
& Hot water use & 3.4 & $1.5-7.9$ & 0.004 \\
& Official milk control implementation & 4.6 & $1.6-13.3$ & 0.003 \\
& Milking mastitic cows at the end & 2.4 & $1.1-5.5$ & 0.04 \\
& Abrupt cessation of milking & 2.0 & $0.9-4.5$ & 0.09 \\
Coliforms $^{\mathrm{c}}$ & Glove use & 5.8 & $1.3-27.0$ & 0.007 \\
& Hot water use & 4.4 & $1.6-12.0$ & 0.002 \\
& Calf suck its dam & 2.7 & $1.0-7.0$ & 0.04 \\
\hline
\end{tabular}

\footnotetext{
${ }^{\mathrm{a}}$ Herds with practice as referent

${ }^{\mathrm{b}}$ Likelihood ratio test (1 d.f.)

${ }^{\mathrm{c}}$ Coliform bacteria: Klebsiella oxytoca, Klebsiella pneumoniae, and Serratia marcescens
} 
under poor udder hygiene. According to these authors, the association between udder hygiene status and contagious mastitis may indicate that control methods for contagious mastitis (e.g., teat dipping and sanitation) are not as effective as expected when udders are dirty. Piccinini et al. (2009) isolated specific strains of $S$. aureus not only from milk but also from the teat skin, suggesting their active role in the epidemiology of the mastitis. Concerning tail cleanliness, several authors were unable to establish a significant improvement in cow udder cleanliness or udder health that could be attributed to tail docking, seeing no advantage in adopting this procedure in order to improve milk quality (Eicher et al. 2001; Tucker et al. 2001; Schreiner and Ruegg 2002; Ruegg 2004).

Milking mastitic cows in no specific order was another practice that significantly affected the $S$. aureus presence in BTM in this study. Riekerink et al. (2006) also observed lower isolation rates for $S$. aureus in BTM belonging to herds with mastitis-affected cows milked separately from healthy females. Teat cups were considered the main transmission vehicle (Benić et al. 2012), and therefore, affected cows should be milked separately or after healthy animals (NMC 2001; Zecconi 2006; Arnold and Bewley 2011; Benić et al. 2012; Middleton 2013).

Milking machine cleanliness and hygiene is a critical point that influences bacterial counts in BTM (Bava et al. 2009; Biggs 2009). In our study, herds without hot water use was 3.4 and 4.4 more likely $(P \leq 0.01)$ to present $S$. aureus and coliform bacteria in BTM, respectively. Bava et al. (2009) observed an increase of coliform bacteria counts in BTM when washing with detergent was performed at $<40{ }^{\circ} \mathrm{C}$. Adequate water temperature is an important factor for milk fat (solidifying at $<35^{\circ} \mathrm{C}$ ) residue removal from the surfaces of the milking equipment (Monken and Ingalls 2002). Also, the cleaning solution activity increases with warm water (Reinemann et al. 2003).

An interesting result in our study was the positive influence of abrupt cessation of milking at dry-off on the presence of $S$. aureus in BTM. The abrupt cessation of milking is a generalized practice in association with antimicrobial intramammary administrations and teat sealants. However, it was recently reported (Zobel et al. 2013) that the gradual cessation of milk in high producing dairy cows could be benefic for animal welfare such as udder engorgement, milk leakage, and lying behavior. Nevertheless, Rajala-Schultz et al. (2005) found that increasing milk yield at dry-off has an effect on the incidence of environmental mastitis but not on other pathogens such as CNS.

Herds without official milk control implementation had 4.6 more chance to present $S$. aureus in bulk milk, and this suggests that this tool is very important for mastitis management. According to the NMC mastitis control plan (NMC 2001), periodic reports regarding affected quarters, individual CCS, time of disease occurrence, antibiotic sensitivity data sets, and the use reports of subclinical and/or clinical mastitis are crucial for overall mastitis control assessment (Wenz 2004).

In the present study, other than the hot water use, the use of gloves and the "calf suck its dam" influenced the presence of coliform bacteria on BTM. The use of gloves is one of the most important measures to prevent mastitis caused by coliform (and $S$. aureus) agents in dairy cows (Petersson-Wolfe et al. 2010; Arnold and Bewley 2011) and are included in the NMC mastitis control plan (NMC 2001). The operator's hands can be a vehicle for bacteria dissemination, and gloves can decrease this spread due to the lower bacteria adhesion to plastic or caoutchouc surfaces (Nickerson 2014). Dufour et al. (2012) observed a decrease of $S$. aureus mastitis prevalence and incidence, even between quarters, when gloves were used by operators. In our study, similar findings were observed for coliform bacteria occurrence in BTM. Concerning the impact of calf suckling, our results are in agreement with the findings of González-Sedano et al. (2010) after evaluation of residual calf suckling effect on clinical and subclinical infections of mastitis in dual-purpose cows concluding that eliminating this practice presents a high risk for development of mastitis. In fact, in highproducing dairy cows, suckling decreases the risk of mastitis in the suckling period and in some cows even for some time after the suckling has been terminated (Krohn 2001).

In conclusion, SCN, S. aureus, and coliform bacteria contamination of BTM from dairy cow herds of São Miguel Island was prevalent. Hot water machine cleanliness seems to be a major factor that increases the chance for both bacteria to be present in BTM. Herds without practices such as high hygiene during milking udder and milking mastitic cows at the end also had more chances to present $S$. aureus in BTM. Coliform bacteria in BTM were also more prevalent in herds without glove use and when calf does not suck its dam. These findings, together with the monitoring of dairy herds conducted by the local plan for control of bovine mastitis, can help to improve the health status of the dairy industry on the island São Miguel Island.

Acknowledgments The authors thank the Associação de Jovens Agricultores Micaelenses (AJAM) and the farms involved in this study. Also, the work carried out by the staff of the Molecular Diagnosis Unit at diagnos (Hipra) is appreciated.

\section{Compliance with ethical standards}

Conflict of interest Carla Azevedo (Technical and Marketing Manager Ruminants for Portugal), Roger Guix (Corporate Marketing Manager Mastitis) and Jaime Maldonado (DIAGNOS Manager) are employed of Hipra SA Laboratorios-Amer (Girona), Spain. The three authors declare that this professional relationship did not affect the design, sample collection, and 
analysis, results, discussion, and conclusions of the present study. Remaining authors declare that they have no conflict of interest.

Open Access This article is distributed under the terms of the Creative Commons Attribution 4.0 International License (http:// creativecommons.org/licenses/by/4.0/), which permits unrestricted use, distribution, and reproduction in any medium, provided you give appropriate credit to the original author(s) and the source, provide a link to the Creative Commons license, and indicate if changes were made.

\section{References}

Arnold, M. and Bewley, J., 2011. Staphylococcus aureus Mastitis. University of Kentucky College of Agriculture, Food and Environment, Lexington, KY. Available online: http://www2.ca. uky.edu/agc/pubs/id/id190/id190.pdf.

Bava, L., Zucali, M., Brasca, M., Zanini, L. and Sandrucci, A., 2009. Efficiency of cleaning procedure of milking equipment and bacterial quality of milk. Italian Journal of Animal Science, 8, 387-389.

Bava, L., Zucali, M., Sandrucci, A., Brasca, M., Vanoni, L., Zanini, L. and Tamburini, A., 2011. Effect of cleaning procedure and hygienic condition of milking equipment on bacterial count of bulk tank milk. Journal of Dairy Research, 78, 211-219.

Benić, M., Habrun, B. and Kompes, G., 2012. Clinical and epidemiological aspects of cow mastitis caused by Staphylococcus aureus and its methicillin-resistant strains. Rad 511- Medical Sciences, 37, 113122.

Berry, D.P., O’Brien, B., O’Callaghan, E.J., Sullivan, K.O. and Meaney, W.J., 2006. Temporal trends in bulk tank somatic cell count and total bacterial count in Irish dairy herds during the past decade. Journal of Dairy Science, 89, 4083-4093.

Biggs, A., 2009. Mastitis in Cattle, (The Crowood Press, Marlborough, Australia).

Bradley, A., 2002. Bovine mastitis: an evolving disease. The Veterinary Journal, 164, 116-128.

Cicconi-Hogan, K.M., Gamroth, M., Richert, R., Ruegg, P., Stiglbauer, K.E. and Schukken, Y.H., 2013. Risk factors associated with bulk tank standard plate count, bulk tank coliform count, and the presence of Staphylococcus aureus on organic and conventional dairy farms in the United States. Journal of Dairy Science, 96, 7578-7590.

Cook, N.B., 2002. The influence of barn design on dairy cow hygiene, lameness and udder health. Proceeding of American Association of Bovine Practitioners, WI. 97-103.

De Vliegher, S., Laevens, H., Barkema, H.W., Dohoo, I.R., Stryhn, H., Opsomer, G. and de Kruif, A., 2004. Management practices and heifer characteristics associated with early lactation somatic cell count of Belgian dairy heifers. Journal of Dairy Science, 87, 937-947.

Dufour, S., Dohoo, I., Barkema, H., Descôteaux, L., Devries, T., Reiher, K., Roy, J. and Scholl, D., 2012. Manageable risk factors associated with the lactational incidence, elimination, and prevalence of Staphylococcus aureus intramammary infections in dairy cows. Journal of Dairy Science, 95, 1283-1300.

Eicher, S.D., MorrowT esch, J.L., Albright. J.L. and Williams, R.E., 2001. Tail docking alters fly numbers, flya voidance behaviors, and cleanliness, but not physiological measures. Journal of Dairy Science, 84, 18221828.

Fregonesi, J.A. and Leaver, J.D., 2001. Behaviour, performance and health indicators of welfare for dairy cows housed in strawyard or cubicle systems. Livestock Production Science, 68, 205-216.

González-Sedano M., Marın-Mejıa B., Maranto M.I., Leme de Magalhães-Labarthe A.C. and Alonso-Diaz M.A., 2010. Effect of residual calf suckling on clinical and sub-clinical infections of mastitis in dual-purpose cows: epidemiological measurements. Research Veterinary Science, 89, 362-366.

Hosmer, D.W. and Lemeshow S., 1989. Applied logistic regression, (Wiley, New York, USA).

Howard, P., 2006. Mastitis pathogens present in bulk tank milk from seven dairy herds in the Waikato region, New Zealand. New Zealand Veterinary Journal, 54, 41-43.

Katholm, J., Bennedsgaard, T.W., Koskinen, M.T. and Rattenborg, E., 2012. Quality of bulk tank milk samples from Danish dairy herds based on real-time polymerase chain reaction identification of mastitis pathogens. Journal of Dairy Science, 95, 5702-5708.

Koskinen, M.T., Holopainen, J., Pyörälä, S., Bredbacka, P., Pitkälä, A., Barkema, H.W., Bexiga, R., Roberson, J., Sølverød, L., Piccinini, R., Kelton, D., Lehmusto, H., Niskala, S. and Salmikivi, L., 2009. Analytical specificity and sensitivity of a real-time polymerase chain reaction assay for identification of bovine mastitis pathogens. Journal of Dairy Science, 92, 952-959.

Krohn C., 2001. Effects of different suckling systems on milk production, udder health, reproduction, calf growth and some behavioural aspects in high producing dairy cows - a review. Applied Animal Behaviour Science,72, 271-280.

Leelahapongsathon, K., Schukken, Y. and Suriyasathaporn, W., 2014. Quarter, cow, and farm risk factors for intramammary infections with major pathogens relative to minor pathogens in Thai dairy cows. Tropical Animal Health and Production, 46, 1067-1078.

Middleton, J.R., 2013. Staphylococcus aureus mastitis: have we learned anything in the last 50 years? Proceedings of the National Mastistis Council Regional Meeting, July 23-24, 2013, Portland, Maine, pp.18.

Monken, A. and Ingalls, W., 2002. Milking system cleaning and sanitizing: troubleshooting milk bacteria counts. Proceedings of the National Mastitis Council Regional Meeting, Kansas City, Missouri, pp. 55-60.

Nickerson, S.C., 2014. Management strategies to reduce heat stress, prevent mastitis and improve milk quality in dairy cows and heifers. University of Georgia, Bulletin 1426. Available online: http:// extension.uga.edu/publications/detail.cfm?number=B1426.

NMC, 2001. National Mastitis Council recommended mastitis control program. Available online: http://www.nmconline.org/docs/ NMCchecklistInt.pdf.

Petersson-Wolfe, C., Mullarky, I. and Jones, G., 2010. Staphylococcus aureus mastitis: cause, detection, and control. College of Agriculture and Life Sciences, Virginia State University, 404-229. Available online: http://pubs.ext.vt.edu/404/404-229/404-229_pdf.pdf.

Phuektes, P., Browning, G.F., Anderson, G. and Mansell, P.D., 2003. Multiplex polymerase chain reaction as a mastitis screening test for Staphylococcus aureus, Streptococcus agalactiae, Streptococcus dysgalactiae and Streptococcus uberis in bulk milk samples. Journal of Dairy Research, 70, 149-155.

Piccinini, R., Cesaris, L., Dapra, V., Borromeo, V., Picozzi, C., Secchi, C. and Zecconi, A., 2009. The role of teat skin contamination in the epidemiology of Staphylococcus aureus intramammary infections. Journal of Dairy Research, 76, 36-41.

Piessens, V., De Vliegher, S., Verbist, B., Braem, G., Van Nuffel, A., De Vuyst, L., Heyndrickx, Mm. and Van Coillie, E., 2012. Intra-species diversity and epidemiology varies among coagulase-negative Staphylococcus species causing bovine intramammary infections. Veterinary Microbiology, 155, 62-71.

Pinto, C.A., 2010. Hematúria Enzoótica Bovina: Contribuição para o seu Estudo Etiopatogénico. Tese de Doutoramento em Ciências Veterinárias, Faculdade de Medicina Veterinária, Universidade Técnica de Lisboa.

Pyörälä, S. and Taponen, S., 2009. Coagulase-negative staphylococciemerging mastitis pathogens. Veterinary Microbiology, 134, 3-8.

Rajala-Schultz, P.J., Hogan, J.S. and Smith, K.L., 2005. Short communication: association between milk yield at dry-off and probability of 
intramammary infections at calving. Journal of Dairy Science, 88, $577-579$.

Reinemann, D.J., Wolters, G.M.V.H., Billon, P., Lind, O. and Rasmussen, M.D., 2003. Review of practices for cleaning and sanitation of milking machines. International Dairy Federation, Brussels, Belgium. Bulletin No. 381/2003, pp. 4-48.

Richard, G.M., Riekerink, O., Barkema, H., Veenstra, S., Poole, D., Dingwell, R.T. and Keefe, G.P., 2006. Prevalence of contagious mastitis pathogens in bulk tank milk in Prince Edward Island. Canadian Veterinary Journal, 47, 567-572.

Riekerink, R.O., Barkema, H., Kelton, D.F., Keefe, G.P. and Scholl, D.T., 2006. Risk factors for herd-level infection of contagious mastitis pathogens on Canadian dairy farms. Proceedings of the 11th International Symposium on Veterinary Epidemiology and Economics, Cairns, Australia, p. 598.

Riekerink, R.O., Barkema, H., Scholl, D.T., Poole, D.E. and Kelton, D.F., 2010. Management practices associated with the bulk-milk prevalence of staphylococcus aureus in Canadian dairy farms. Preventive Veterinary Medicine, 97, 20-28.

Ruegg, P.L., 2004b. Tail Docking and Animal Welfare. The Bovine Practitioner, 38, 24-29.

Rysanek, D., Babak, V. and Zouharova, M., 2007. Bulk tank milk somatic cell count and sources of raw milk contamination with mastitis pathogens. Veterinarni Medicina, 52, 223-230.

Rysánek, D., Zouharová, M. and Babák, V., 2009. Major mammary pathogens as contributors to total bacterial counts in raw milk. Acta Veterinaria Brno, 78, 455-461.

SAS Institute Inc., 2007. JMP User's Guide. Version 7.0. SAS Institute Inc: Cary, NC, USA.

Schreiner, D.A. and Ruegg, P.L., 2002. Effects of tail docking on milk quality and cow cleanliness. Journal of Dairy Science, 85, 25032511.

Schreiner, D.A. and Ruegg, P.L., 2003. Relationship between udder and leg hygiene scores and subclinical mastitis. Journal of Dairy Science, 86, 3460-3465.
Schukken, Y.H., González, R.N., Tikofsky, L.L., Schulte, H.F., Santisteban, C.G., Welcome, F.L., Bennett, G.J., Zurakowski, M.J. and Zadoks, R.N., 2009. CNS mastitis: nothing to worry about? Veterinary Microbiology, 134, 9-14.

SDASM, 2014. Serviços de Desenvolvimento Agrário de São Miguel. Governo dos Açores. Available online: http://www.azores.gov.pt.

SREA, 2014. Entrega de leite na fábrica. Available online: http:// estatistica.azores.gov.pt/.

Taponen, S., Salmikivi, L., Simojoki, H., Koskinen, M.T. and Pyörälä, S., 2009. Real-time polymerase chain reaction-based identification of bacteria in milk samples from bovine clinical mastitis with no growth in conventional culturing. Journal of Dairy Science, 92, 2610-2617.

Tucker, C.B., Fraser, D. and Weary, D.M., 2001. Tail docking dairy cattle: effects on cow cleanliness and udder health. Journal of Dairy Science, 84, 84-87.

Vanderhaeghen, W., Piepers, S., Leroy, F., Van Coillie, E., Haesebrouck, F. and De Vliegher, S., 2015. Identification, typing, ecology and epidemiology of coagulase negative staphylococci associated with ruminants. The Veterinary Journal, 203, 44-51

Wenz, J.R., 2004. Practical monitoring of clinical mastitis treatment programs. Proceedings of the 43rd Annual Meeting of the National Mastitis Council, Charlotte, NC, pp.41-46.

Zadoks, R.N., Allore, H.G., Barkema, H.W., Sampimon, O.C., Wellenberg, G.J., Grohn, Y.T. and Schukken, Y.H., 2001. Cowand quarter-level risk factors for Streptococcus uberis and Staphylococcus aureus mastitis. Journal of Dairy Science, 84, 2649-2663.

Zecconi, A., 2006. Can we eradicate staphylococcus aureus mastitis? Proceedings of the 24th World Buiatrics Congress, October 15-19, Nice, France, pp. 225-236.

Zobel, G., Leslie, K., Weary, D.M. and von Keyserlingk, M.A., 2013. Gradual cessation of milking reduces milk leakage and motivation to be milked in dairy cows at dry-off. Journal of Dairy Science, 96, 5064-5071. 